\title{
Effects of long-term use of different farming systems on some physical, chemical and microbiological parameters of soil quality**
}

\author{
Anna M. Gajda ${ }^{*}$, Ewa A. Czyżं and Anthony R. Dexter ${ }^{2}$ \\ ${ }^{1}$ Department of Agricultural Microbiology, ${ }^{2}$ Department of Soil Science and Land Protection, \\ Institute of Soil Science and Plant Cultivation, State Research Institute, Czartoryskich 8, 24-100 Puławy, Poland \\ ${ }^{3}$ Department of Soil Science, Environmental Chemistry and Hydrology, University of Rzeszów, \\ Zelwerowicza 8b, 35-601 Rzeszów, Poland \\ Received February 12, 2015; accepted September 28, 2015
}

\begin{abstract}
The aim of this study was to compare the effects of different farming systems (organic, integrated, conventional and monoculture) on some soil properties as: bulk density, contents of readily-dispersible clay, organic matter and particulate organic matter, and enzymatic activity measured in terms of the intensity of fluorescein diacetate hydrolysis. Soil under permanent grass was used as a control. The study was conducted on the 20 years lasting field experiment. Samples of Haplic Luvisol soil were collected twice a year on fields under winter wheat from the layers of 0-5, 5-10, 15-20, and 30-35 cm. Within arable soils the soil under organic farming contained the greatest amount of organic matter, which influenced strongly the readily-dispersible clay content, especially in the layer of $5-20 \mathrm{~cm}$. The readily-dispersible clay content in soil under organic farming was 3 times lower, as compared to the conventional and monoculture farming. The highest contents of particulate organic matter 6.2 and $3.5 \mathrm{mg} \mathrm{g}^{-1}$ air dry soil, on average were measured in the $0-5 \mathrm{~cm}$ layer of control soil and soil under organic farming, respectively. Also, soil under organic farming and control soil from the depth of 0-5 $\mathrm{cm}$ showed 2-2.5 times greater activity of microorganisms in fluorescein diacetate hydrolysis than soil under conventional and monoculture farming. Increase of concentration of organic matter in soil under organic farming decreased soil bulk density. Statistical analysis showed significant correlations between studied parameters of soil quality and confirmed their effectiveness as indicators of disturbances in soil environment.
\end{abstract}

K e y w o r d s: different farming systems, organic matter, soil bulk density, readily-dispersible clay, particulate organic matter content, fluorescein diacetate hydrolysis

\section{INTRODUCTION}

Agricultural practice in Poland typically uses conventional plough cultivation for cereal crop production. Evaluation of the effects of different management systems

\footnotetext{
*Corresponding author e-mail: Anna.Gajda@iung.pulawy.pl

**The research was done under Statute Research Project 3.1.4 and partly under grant PIB-IUNG 2.3 and 1.2, 2011-2015.
}

on soil condition is crucial for monitoring and understanding the impact of management practices on soil properties and sustainability of soil productivity (Askari and Holden, 2015; Karlen et al., 2013; Król et al., 2013; Martyniuk et al., 2015). The soil quality concept proposed by Doran and Parkin (1994) which offers an integrated approach of multiple indicator properties together, in the context of crop production should be focused on both agricultural and environmental sustainability as sensitive indicators of ecosystem functions and stability.

Soil organic matter (SOM) has long been considered the key quality factor affecting the physical, chemical and biological properties of soil. Organic matter in soil is often defined as a series of fractions with different rate of decomposition (Doran and Parkin, 1996; Rosell et al., 2001). Baldock and Skjemstad (2000) pointed out the strong relationships of soil organic matter content with soil texture which is the one of the most important factors affecting concentration of OM in soil.

Bulk density (BD) is a major factor in soil compaction and will obviously be changed almost immediately following tillage-induced soil disturbance. Intense operation of heavy machinery and implements in the field causes soil compaction which may increase bulk density and reduce the transportation of water and air through the soil. Consequently, it contributes to the decline in nutrients content in soil, which in turn leads to a decrease in crop yield. Also, the bulk density tells a lot about the porosity status of soil (Dexter et al., 2008; Doran and Parkin, 1996).

(C) 2016 Institute of Agrophysics, Polish Academy of Sciences 
Among the physical fractions, the clay fraction is the most important component of soil. The clay fraction is defined as the fraction of soil particles with effective diameters of less than $2 \mu \mathrm{m}$. Clay is a colloid fraction which plays an important role in the gluing together of larger particles of soil and making the resulting compound particles more stable. In aqueous solution, clay particles can flocculate or disperse. Dispersed clay is mobile in the environment and with run-off water can be transferred across soil surface or with infiltrating water downwards within soil profile, which can have consequences in agriculture and the environment (Czyż and Dexter, 2008, 2009, 2011, 2015). The readilydispersible clay (RDC) has a dynamic nature and its content in soil changes with many factors, eg wetting and drying of soil, and the soil organic matter content. An explanation and more information are given in Czyż and Dexter (2015).

Particulate organic matter (POM) - a transitional, heterogeneous fraction of organic matter $(\mathrm{OM})$ is an intermediate form in the decay continuum between fresh organic residues and humified OM in soil (Cambardella and Elliot, 1992; Cambardella et al., 2001; Gajda et al., 2001; Wander, 2004). The tillage practice influences the POM content in soil which depends on soil type and quality of residues input (Álvaro-Fuentes et al., 2008; Sainju et al., 2006). POM plays an important role in aggregate formation in soils and temporarily provides easily available nutrients for microorganisms and plants. Many researchers have used the POM fraction as an indicator of OM status in soil and recognised POM as a potential indicator of changes in soil quality in the short term (Sequeira et al., 2010; Yoo and Wander, 2008).

The size and activity of microbial populations inhabiting soil are directly related to the quantity and quality of organic carbon and other nutrients available in soil-derived organic amendments and crop residues. Soil enzymes are primarily of microbial origin (Bandick and Dick, 1999) and catalyse all biochemical reactions in soil, and are an integral part of nutrients cycling (Acosta-Martinez et al., 2008; Bandick and Dick, 1999). Some researchers observed significant changes in soil enzymatic activity related to various tillage and cropping management systems (Dick et al., 1996; Marinari et al., 2006).

Hydrolysis of fluorescein diacetate (FDA) in soil is mediated by such non-specific enzymes as lipases, proteases and esterases. Over the last few decades FDA hydrolysis has been widely used as a suitable index of the overall activity of enzymes and microorganisms in soil (Bandick and Dick, 1999; Green et al., 2006). Also, the rate of FDA hydrolysis in soil has been suggested as a suitable parameter for the monitoring of soil quality and bioecosystem studies (Green et al., 2006).

The objective of this study was to determine the effects of long-term use of different farming systems on changes in physical (BD, RDC), chemical (OM, POM content) and enzymatic activity in soil measured in terms of the intensity of FDA hydrolysis.

\section{MATERIALS AND METHODS}

The three year studies (2011-2013) were conducted in a long-term field experiment established in 1994 at the Osiny Experimental Station $\left(51^{\circ} 28^{\circ} \mathrm{N}, 2^{\circ} 30^{`} \mathrm{E}\right)$ (Lublin voivodeship) belonging to the Institute of Soil Science and Plant Cultivation, State Research Institute (IUNG-PIB) in Puławy, Poland. The experimental fields, with area of about 1 ha each, are situated predominantly on Haplic Luvisol soil. Some selected properties of the soil are presented in Table 1. More information about the field experiment can be found in Król et al. (2013), Kuś and Jończyk (2008), and Martyniuk et al. (2015).

Crops in this experiment were grown in different farming systems on non-replicated fields.

The organic farming system (ORG) consisted of 5 fields on which the following crops were rotated: potato - spring barley + intercrop - grass/clover mixture (1st year) - grass/ clover mixture (2nd year) - winter wheat. In this system $30 \mathrm{t} \mathrm{ha}^{-1}$ of grass/clover compost was applied under potato crop and a biological preparation against potato beetle was used. This system supplied a relatively high amount of crop residues which was incorporated into the soil each year. No mineral fertilisers and plant protection chemicals were used. Weed control was based mainly on mechanical treatments. The integrated farming system (INT) consisted of 4 fields on which the following crops were rotated: potato - spring wheat + intercrop - faba bean - winter wheat + aftercrop. Balanced mineral fertilization with phosphorus and potassium applied in this system was based on calculations of the amount of nutrients taken-up by the crops and removed with harvested crops from the fields. Doses of nitrogen were calculated on the basis of results obtained from adequate soil and plant tests performed. Weed control was applied mainly with consideration of thresholds of harmfulness of agrophages. Organic fertilization at the rate of $30 \mathrm{tha}^{-1}$ (similarly as in the organic farming system) and intercrop ploughed down were applied into the soil under potatoes.

The most intensive were two conventional farming systems with mouldboard ploughing inverting the top of soil up $20 \mathrm{~cm}$. The conventional farming system $(\mathrm{CON})$ consisted of 3 fields on which the following crops were rotated: winter rape-winter wheat-spring barley. In the winter wheat monoculture-conventional farming system (MON) winter wheat was cultivated every year on the same field. In both conventional farming systems the crops were grown according to the high input recommendations generally used in Poland. Organic fertilization was limited to the winter rape, and winter wheat straw was spread on the field surface after the fall harvest and ploughed down into the soil. The tillage treatment for each plot always remained the same.

To better demonstrate the differences between the effects of farming systems on the soil environment, the long-term uncultivated loamy sand soil under permanent grass was collected, as an uncultivated control (CNT). 
Representative soil samples (about $1500 \mathrm{~g}$ each) were taken twice in every growing season when wheat entered the maturity stage (in mid-June) and just before harvest from in-row planting area at the depths of 0-5, 5-10, 15-20 and $30-35 \mathrm{~cm}$ across each trial. Soil samples were first weighted, then thoroughly mixed and about $15 \mathrm{~g}$ subsamples were dried at $105^{\circ} \mathrm{C}$ for $24 \mathrm{~h}$ to determine soil water content. For microbiological analysis soil samples were sieved through $2 \mathrm{~mm}$ mesh sieve.

The 3,6-diacetylfluorescein (FDA) hydrolysis activity of the soil was determined by measuring the concentration of fluorescein released after soil incubation at $490 \mathrm{~nm}$ using the method described by Dick et al. (1996). All enzyme assays were triplicated using controls without substrate to correct for background. Enzyme activity was reported as $\mu \mathrm{g}$ of product formed $\mathrm{g}^{-1}$ dry weight of soil $\mathrm{h}^{-1}$.

The content of POM fraction was measured according to the modified Cambardella et al. (2001) method in which POM was estimated using loss-on-ignition (LOI) procedure (Schulte and Hopkins, 1996), as detailed by Gajda et al. (2001). POM expressed as \% of OM was evaluated for the arable and sub-arable layers of soil at the depth of 0-20 and 30-35 cm, respectively.

Analyses of microbiological activity of soil and POM content were performed in the Department of Agricultural Microbiology at IUNG-PIB in Puławy, Poland.

The particle size distribution of the soil (sieving and sedimentation) was determined using the Cassagrande aerometric method modified by Prószyński (PN-R-04032, 1998). The soil type was identified according to the Polish Society of Soil Science (PTG-2008).

RDC content in soil was measured in ten replicates for each farming system separately using a $\mathrm{HACH}$ turbidimeter model 2100 (Czyż and Dexter, 2015).

Soil OM content was measured by wet oxidation using the Tiurin method. Soil bulk density $\left(\mathrm{Mg} \mathrm{m}^{-3}\right)$ was calculated using the weight and volume of soil (Czyż and Dexter, 2008). Bulk density and RDC content were determined for soil taken at the depths of $0-20,30-35$ and $5-20,30-35 \mathrm{~cm}$, respectively.

The particle size distribution, bulk density (BD), readilydispersible clay (RDC) and organic matter (OM) content determinations were carried out in the Department of Soil Sciences Erosion and Land Conservation at IUNG-PIB in Puławy, Poland.

The soil $\mathrm{pH}$ was measured by the potentiometric method using a glass electrode in soil suspension in $1 \mathrm{M}$ potassium chloride solution (1:2 solid:liquid mixture). Available phosphorus and potassium content in soil were determined by the Egner-Riehm method in the central certified laboratory belonging to the IUNG-PIB in Puławy, Poland.

Statistical analyses were carried out using the ANOVA method and the $95 \%$ confidence limit $(p<0.05)$ was chosen to indicate the significance of differences between studied parameters of soil physical, chemical and biological properties.

\section{RESULTS AND DISCUSSION}

The effects of different farming systems on soil have been intensively studied. Great attention was paid to the effects of such practices on changes in quantity of organic matter $(\mathrm{OM})$ in soil and its composition. The content of $\mathrm{OM}$ in arable soil under different farming systems and uncultivated control soil is presented in Fig 1. The highest concentration of OM $(1.98 \%)$ was measured in the control soil (CNT) in the layer at the depth of $0-5 \mathrm{~cm}$. Also, quite a high content of OM (1.66\%) was determined in the lower layer of CNT soil at the depth of $5-10 \mathrm{~cm}$. For the layer of 0-10 cm depth of CNT soil the content of OM amounted to $1.82 \%$. The soil under ORG farming system, where a plough was not used, showed a significantly higher content of OM (1.68\%) in 0-10 cm soil layer as compared to the soil under the other farming systems, most of all the CON and MON, both based on intensive plough operations. The determined quantity of $\mathrm{OM}$ in soil under $\mathrm{CON}$ and MON farming systems reached the concentration of 1.18 and $1.25 \%$, respectively. In the soil under the integrated (INT) farming system the quantity of OM reached $1.21 \%$ (Table 1).

The most distinctive difference between tillage with soil inversion and no-tillage is in the top soil - the first few centimeters soil layer (Franzluebbers, 2002). The farming systems based on plough operations tend to homogenise the soil within the depth affected by implements, in contrast to no-tillage, where the residue accumulates mainly at the soil surface and does not involve soil disturbance and movement (Salvo et al., 2010). Our results are in agreement with previous findings mentioned above.

After three years of the study the effect of farming systems on soil bulk density (BD) was noticed. The BD of soil (0-20 cm layer) under the CON, INT and MON farming systems showed higher values ( $1.63 \mathrm{Mg} \mathrm{m}^{-3}$, on average) as compared to BD measured in soil under the ORG farming system (1.58 $\mathrm{Mg} \mathrm{m}^{-3}$, on average), but the significance of these results was not meaningful at $p<0.05$. The differences in DB did not show any statistical significance between the CON, INT and MON farming systems either $(0-20 \mathrm{~cm}$

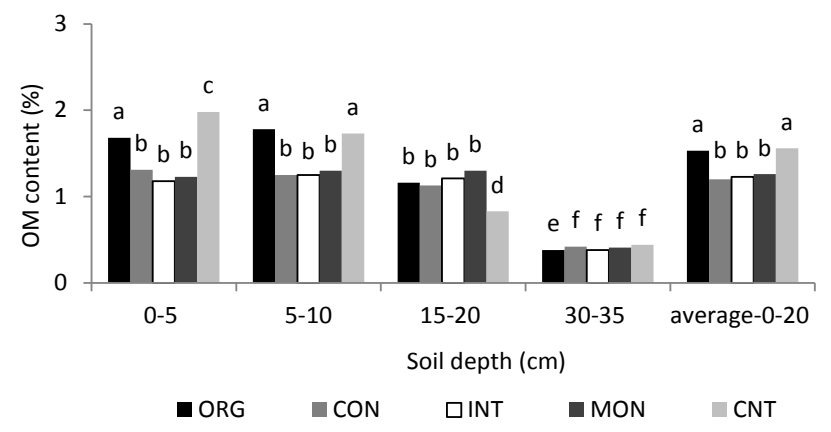

Fig. 1. Organic matter content in soil under different farming systems. Values marked with different letters are statistically significant at $\mathrm{p} \leq 0.05$. 
T a b l e 1. Some physical and chemical properties of examined soil $(0-10 \mathrm{~cm})$

\begin{tabular}{|c|c|c|c|c|c|c|c|c|c|}
\hline \multirow{2}{*}{$\begin{array}{c}\text { Farming } \\
\text { system }\end{array}$} & \multicolumn{3}{|c|}{ Soil texture, mm (\%) } & \multirow{2}{*}{ Soil type } & \multirow{2}{*}{$\begin{array}{l}\mathrm{OM} \\
(\%)\end{array}$} & \multirow{2}{*}{$\begin{array}{c}\mathrm{pH} \\
\mathrm{KCl}\end{array}$} & $\mathrm{P}_{2} \mathrm{O}_{5}$ & $\mathrm{~K}_{2} \mathrm{O}$ & $\mathrm{Mg}$ \\
\hline & $2-0.05$ & 0.05-0.002 & $<0.002$ & & & & \multicolumn{3}{|c|}{ (mg $100 \mathrm{~g}^{-1}$ soil) } \\
\hline ORG & 77 & 21 & 2 & & 1.68 & 5.7 & 17.8 & 9.2 & 6.0 \\
\hline $\mathrm{CON}$ & 75 & 22 & 3 & & 1.17 & 6.1 & 14.7 & 21.4 & 19.9 \\
\hline INT & 82 & 15 & 3 & $\begin{array}{l}\text { loamy } \\
\text { sand }\end{array}$ & 1.02 & 5.2 & 8.0 & 16.1 & 13.6 \\
\hline MON & 78 & 21 & 1 & & 1.28 & 5.9 & 19.3 & 14.2 & 17.2 \\
\hline CNT & 77 & 21 & 2 & & 1.65 & 4.4 & 16.3 & 16.0 & 6.3 \\
\hline
\end{tabular}

$\mathrm{ORG}$ - organic farming system, CON - conventional farming system, INT - integrated farming system, MON - winter wheat monoculture-conventional, CNT- control soil (permanent grass).

depth). The only significant differences in BD measurement were obtained for soil under the CON, INT, MON farming systems and CNT soil which reached $0.13 \mathrm{Mg} \mathrm{m}^{-3}$ (8.0\%), on average (Fig. 2).

In the lower layer of soil, $30-35 \mathrm{~cm}, \mathrm{BD}$ was about $31 \%$ higher, on average, as compared to soil BD in the layer of $0-20 \mathrm{~cm}$. The significance of obtained differences in BD between soil layers studied was confirmed statistically. In comparison to other studied farming systems, higher value of $\mathrm{BD}$ was obtained in the $30-35 \mathrm{~cm}$ layer of soil under the ORG farming system $1.83 \mathrm{Mg} \mathrm{m}^{-3}$, but the deference was not significant. There were no significant differences between the CON, INT and MON farming systems in soil $\mathrm{BD}$ in the layer of $30-35 \mathrm{~cm}$, also.

Trends observed in the measurements of BD allow to conclude that farming systems based on less invertible management enhanced the decrease of BD, especially at $0-20 \mathrm{~cm}$ depth, contrary to the CON farming system. Changes in BD of arable soil were much more clearly seen as compared to the uncultivated CNT soil (Fig. 2). Similar results have been published by Rahman et al. (2008). Furthermore, Dao (1996) reported that non-tilled soil had lower BD than conventionally-tilled soil. Though, Ishaq et al. (2002) reported that no significant effect of tillage methods on soil $\mathrm{BD}$ was noticed. Rasmussen (1999) remarked that these contradictory results may be due to differences in crop species, soil properties, climatic characteristics and complex interactions of all these factors. Additionally, an amount of crop residues incorporated into soil may enhance changes in BD measurements, what probably influenced also the changes in measurements of soil BD in our farming systems (Fig. 2).

The changes in the content of readily-dispersible clay (RDC), determining soil stability in water, are presented in Fig. 3. The soil under the $\mathrm{CON}$ and MON farming systems contained the highest amounts of RDC. In both, 5-20 and $30-35 \mathrm{~cm}$ layers of soil under intensive tillage systems the

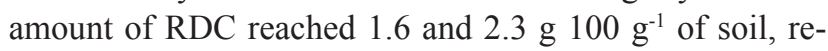
spectively. The most beneficial effects on decrease of RDC content were observed in soil under the ORG farming system. At the depth of 5-20 cm, the measured content of RDC

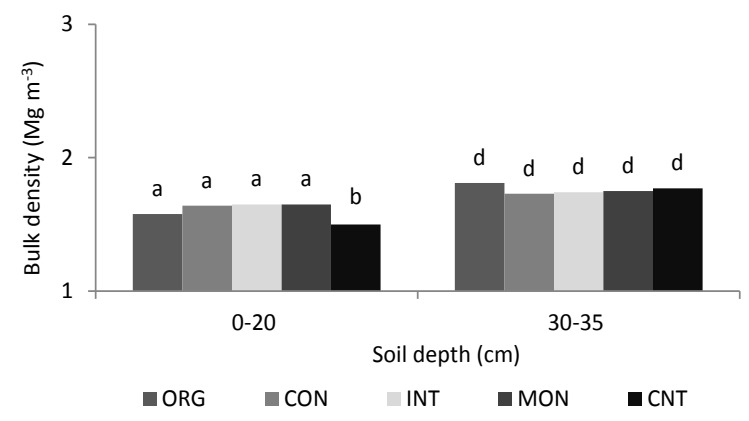

Fig. 2. The effect of the different farming systems on soil bulk density. Explanations as in Fig. 1.

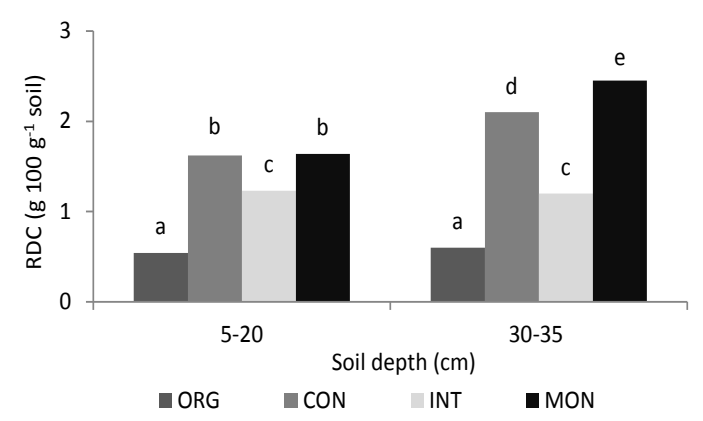

Fig. 3. The effect of the different farming systems on readilydispersible clay (RDC) content in soil. Explanations as in Fig. 1.

was 3 times lower as compared to the CON and MON farming systems. At the lower layer of soil $(30-35 \mathrm{~cm})$ under the CON and MON farming systems the content of RDC was $24 \%$ higher as compared to arable soil at layer of $5-20 \mathrm{~cm}$. In soil under the INT farming system the content of RDC

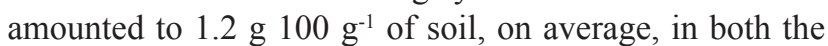
arable $(5-20 \mathrm{~cm})$ and subsoil $(30-35 \mathrm{~cm})$ layers (Fig. 3).

As it was written by Etana et al. (2009), previous studies (Reeves, 1997; Tebrüge and Düring, 1999) showed that the accumulation of soil organic matter in the upper plough layer increases more in treatments with shallow tillage than in those with mouldboard ploughing. Our results indicate that the CON and MON farming systems based 
on plough operation affected the soil unfavourably, enhancing the decrease of soil stability in water and increasing the susceptibility of the soil to erosion processes. Higher concentration of organic matter in soil influenced the decrease in RDC content. According to Czyż et al. (2002) and Dexter et al. (2008) the total organic C controls mainly the RDC, and then RDC shows a similar outcome to organic matter, but since it is the complex-bound $\mathrm{C}$ a similar outcome could not be expected for RDC. As Czyż and Dexter (2015) reported, an increase of organic matter content in soil was found to reduce the amount of RDC in a Polish soil (Dexter and Czyż, 2000), in Romanian soils (Watts et al., 1996b), and for a UK soil (Watts and Dexter, 1997). Different tillage or other inputs of mechanical energy to soil increase the amount of RDC (Czyż and Dexter, 2009, 2015; Watts et al., 1996a,c).

The management practices affected not only the quantity of total soil OM, but its quality as well. The effects of different farming systems on the content of biologically active soil organic matter fraction POM are presented in Fig. 4. The highest content of POM was measured in the uncultivated control soil, at $6.2 \mathrm{mg} \mathrm{g}^{-1}$ air dry soil, on average, in the layer of $0-5 \mathrm{~cm}$. Among the farming systems, soil under the ORG farming showed the highest content of POM fraction $-3.5 \mathrm{mg} \mathrm{g}^{-1}$ a.d. soil.

Under the CON farming system based on ploughing, the quantity of POM fraction was recorded at the significantly lower level of $2.7 \mathrm{mg} \mathrm{g}^{-1}$ a.d. soil, as compared to CNT soil and soil under the ORG farming system. A difference in POM quantity, significant at $\mathrm{p}<0.05$, of about $55.6 \%$, on average, was obtained between CNT soil and the soil under the farming systems studied (ORG, CON, INT, $\mathrm{MON}$ ), at the depth of $5-10 \mathrm{~cm}$.

At the soil layer of $15-20 \mathrm{~cm}$, about $25 \%$ greater content of POM was estimated in soil under CON and MON farming systems in relation to the less disturbing ORG and INT farming systems. Moreover, in the same soil layer about $43 \%$ lower quantity of POM was recorded in CNT soil in relation to the average POM content in the soil under the farming systems studied. There were no significant differences in the quantities of POM as influenced by the farming systems at the $30-35 \mathrm{~cm}$ subsoil layer. Also, soil at the layer of $0-20 \mathrm{~cm}$ did not show any significant differences between the farming systems in the average contents of POM (Fig. 4). The effects of ORG, INT and MON farming systems and no-till on POM quantity in relation to CON farming system are presented in Fig. 5. The highest increase of POM (about $23 \%$ ) was noted in $0-5 \mathrm{~cm}$ soil under the ORG farming system. The decrease of biologically-active fraction of OM reached the highest values in the soil layer at $15-20 \mathrm{~cm}$ depth under the INT and ORG systems, 29 and $25 \%$ on average, respectively. In the soil layer of $30-35 \mathrm{~cm}$ under the ORG, INT and MON farming systems the decrease of POM reached $14.3 \%$, on average, in relation to the corresponding soil layer under the CON system.

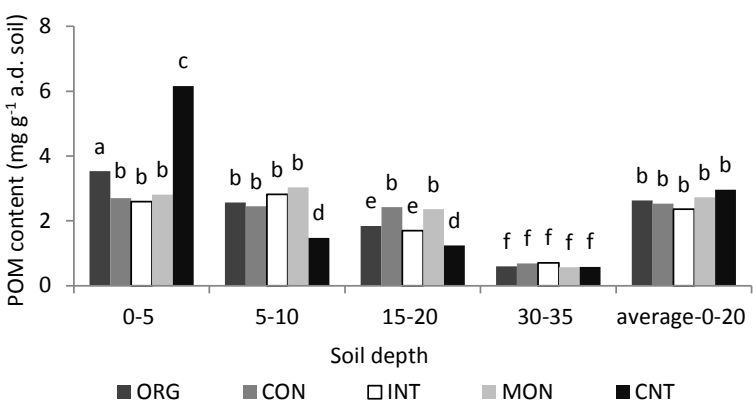

Fig. 4. POM content in soil under different farming systems. Explanations as in Fig. 1.

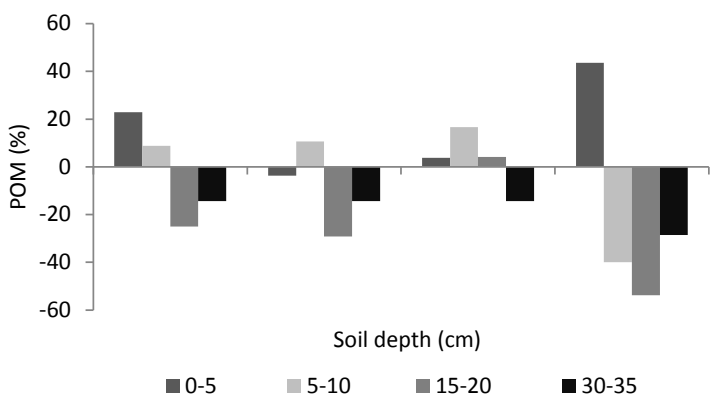

Fig. 5. Increase and/or decrease of POM quantity in studied layers of soil under ORG, INT, MON farming systems and uncultivated CNT soil versus CON farming system after three-year studies.

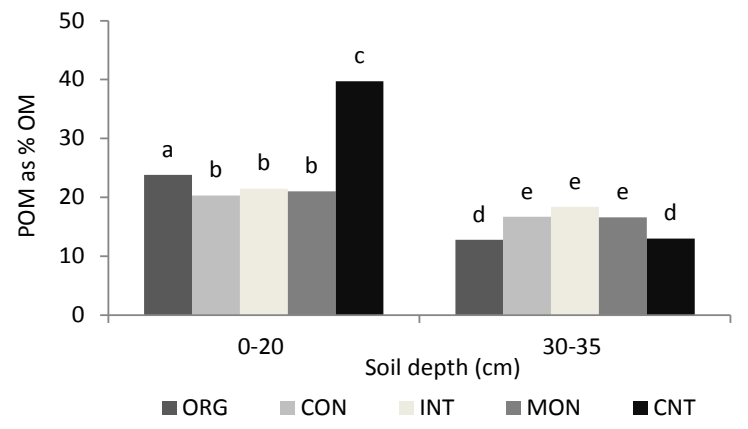

Fig. 6. $P O M$ fraction expressed as a $\%$ of $O M$ in arable and sub-arable layer of soil under the different farming systems. Explanations as in Fig. 1.

For better picture of obtained differences in the effects of farming systems on the soil environment the uncultivated soil (CNT) was analysed as a specific control. The differences in changes of POM quantity in the control soil (in $0-5 \mathrm{~cm}$ soil $44 \%$ increase; in $5-20 \mathrm{~cm}$ soil $41 \%$ decrease, on average) in relation to the soil under CON farming system were the highest among all studied soil depths (Fig. 5).

In both layers of the soil, 0-20 and 30-35 cm, the POM fraction represented a relatively small percentage of total OM, at 20-24 and 13-18\%, on average, respectively (Fig. 6). These results are in agreement with values in the range of $10-30 \%$ as reported in literature (Martin-Lammerding et al., 2013; Wander, 2004). In the control soil (CNT) the contribution of POM in total OM in the $0-20 \mathrm{~cm}$ depth reached 
about $40 \%$, but in the sub-arable soil layer $(30-35 \mathrm{~cm})$ it remained on a similar level ( $13 \%$, on average) to the corresponding layer of soil under ORG farming (Fig. 6). Similar results were obtained in earlier studies of Gajda (2010).

The results confirmed that the percentage of the totally and/or partly humified fraction of OM (POM) in the total content of OM decreased significantly with soil depth, especially in soil under no-till system and non-inversion tillage. Some other researchers also observed similar variations in measurements of $\mathrm{POM}$ and $\mathrm{OM}$ quantities in pastoral and zero-till soils (Gupta et al., 1994; Haynes, 1999). In intesively-ploughed soil under CON and MON farming systems changes in the percentage of POM in total OM were not significant in both $0-20$ and $30-35 \mathrm{~cm}$ soil layers. Besides, a small increase of totally and/or partly humified fraction and soil OM was noted even in the subarable layer (Figs 1, 6).

According to Wander (2004), a large proportion of the POM fraction belongs to the labile soil OM pool and is physically protected within soil aggregates, and may be mineralised more quickly, especially if soil is disturbed (eg with mouldboard ploughing) and these aggregates broken. With reducing tillage intensity, the process of soil aggregation may increase and offer some protection to the POM fraction as well (Martin-Lammerding et al., 2011).

In soil which has not been tilled the input of fresh and easily decomposable plant material, such as grass top and roots, decreases as a function of depth, which was also reflected in our studies in the distribution of $\mathrm{OM}$ and its component POM in the soil profile (Figs 1, 4, 6).

The farming practices significantly affected the activity of microorganisms in the soil habitat as measured with FDA hydrolysis. The FDA hydrolysis activity which is involved in the transformation of soil OM reached the highest values in the control soil and in the soil under the ORG farming, mainly due to high deposition of plant residues.

In comparison to tillage with soil inversion (CON and MON farming systems), 2 and 2.5 times higher activity of microorganisms in FDA hydrolysis in soil under the ORG farming system and in the control (CNT) soil were recorded at the depth of 0-5 cm. In relation to the soil under INT farming system, the activity of microorganisms in FDA hydrolysis process in soil under the $\mathrm{CON}$ and MON systems was lower only 1.3 times. Similar patterns in the rate of FDA hydrolysis were observed in the soil layer at $5-10 \mathrm{~cm}$ depth. The obtained values of FDA hydrolysis measurement in 5-10 cm soil layer under ORG farming system and CNT were 1.8 times smaller, on average, as compared to the top soil horizon $(0-5 \mathrm{~cm})$. There were no significant differences in the activity of FDA hydrolysis between depths 0-5 and 5-10 $\mathrm{cm}$ in soil under the CON and INT farming systems. The rate of FDA hydrolysis dropped gradually with an increase of soil depth. At the $15-20 \mathrm{~cm}$ layer the activity of microorganisms in FDA hydrolysis in soil under ORG system and CNT was 2.7 times lower, on ave- rage, as compared to the $0-5 \mathrm{~cm}$ layer. Also, in the $15-20 \mathrm{~cm}$ layer of soil under the CON, INT and MON farming systems FDA was hydrolyzed 1.1-1.3 times slower then in the soil layer of $0-5 \mathrm{~cm}$. The subsoil layer $(30-35 \mathrm{~cm})$ showed the lowest microbial activity in FDA hydrolysis under all studied farming systems (Fig. 7). Also, Stott and Diack (2004) reported that mean values of fluorescein released in no-till were 14 and 30\% greater than in chisel and mouldboard plough systems, respectively. Gregorich et al. (1994) and Lopez et al. (2010) suggested that enzyme activities are generally the most sensitive indicators of farming systems, where crop residue management affects the belowground microbial community. The results obtained in our studies showed that FDA hydrolysis was a sensitive indicator of the effects of farming systems on the soil environment.

A significant influence of $\mathrm{OM}$ on a range of physical (Czyż et al., 2002; Czyż and Dexter, 2009; Dexter and Czyż 2000; Dexter et al., 2008; Watts et al., 1996a,b,c) and biological (Askari and Holden, 2015; Doran and Parkin, 1994, 1996; Marinari et al., 2006) properties of soil has been reported.

The concentration of OM influenced strongly the bulk density (BD), readily-dispersible clay content (RDC) and biological activity expressed as the FDA hydrolysis mostly in the surface soil horizon, as confirmed by the high linear correlations obtained between soil properties and soil OM content (Table 2).

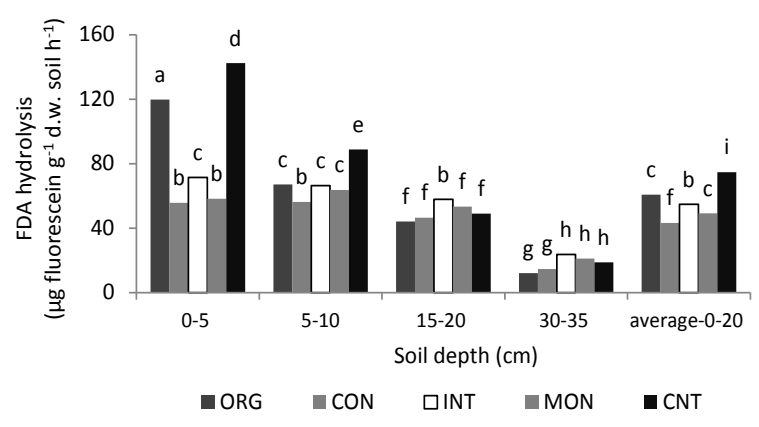

Fig. 7. Effect of the different farming systems on FDA hydrolysis activity in soil. Explanations as in Fig. 1.

T a b l e 2. Relationship between organic matter (OM) and some physical, chemical and biological properties of soil under different farming systems

\begin{tabular}{lcl}
\hline $\begin{array}{l}\text { Related soil } \\
\text { parameters }\end{array}$ & $\begin{array}{c}\text { Correlation } \\
\text { coefficient }(\mathrm{r})\end{array}$ & Linear equation \\
\hline $\mathrm{OM}-\mathrm{BD}$ & $-0.708^{*}$ & $\mathrm{y}=-0.173 \mathrm{x}+1.854$ \\
$\mathrm{OM}-\mathrm{RCD}$ & $-0.607^{*}$ & $\mathrm{y}=-0.544 \mathrm{x}+1.574$ \\
$\mathrm{OM}-\mathrm{FDA}$ & $0.886^{* *}$ & $\mathrm{y}=40.606 \mathrm{x}-0.991$ \\
$\mathrm{OM}-\mathrm{POM}$ & $0.860^{*}$ & $\mathrm{y}=0.677 \mathrm{x}+1.690$ \\
\hline
\end{tabular}

$\mathrm{OM}$ - organic matter content, $\mathrm{BD}$ - bulk density, RDC - readilydispersible clay, FDA - FDA hydrolysis activity, POM - particulate organic matter, statistical significance: ${ }^{*} \mathrm{p} \leq 0.05$, $* * \mathrm{p} \leq 0.01$. 
There are often inverse relationships between $\mathrm{BD}, \mathrm{RDC}$ and OM contents in soil, as it was reported by Czyż and Dexter (2015) and Stutter et al. (2009).

\section{CONCLUSIONS}

1. The studied parameters of physical, chemical and biological properties of soil were influenced significantly by organic matter content.

2. Among the farming systems studied, the organic farming enhanced an increase of organic matter concentration in soil the most, which was reflected in an increase of percentage of particulate organic matter fraction in total organic matter and a higher activity of microorganisms as measured by fluorescein diacetate hydrolysis.

3. Higher concentration of organic matter in soil under organic farming system as compared to soil under other farming systems decreased positively soil bulk density, readily-dispersible clay content and increased the values of the microbiological parameters studied.

4. The studies showed that the parameters: bulk density, readily-dispersible clay content, particulate organic matter fraction and fluorescein diacetate hydrolysis should be considered as being important for maintaining the ability of soils to function.

\section{REFERENCES}

Acosta-Martinez V., Acosta-Mercado D., Sotomayor-Ramirez D., and Cruz-Rodriguez L., 2008. Microbial communities and enzymatic activities under different management in semiarid soils. Applied Soil Ecol., 38, 249-260.

Askari M.S. and Holden N.M., 2015. Quantitative soil quality indexing of temperate arable management systems. Soil Till. Res., 150, 57-67.

Álvaro-Fuentes J., López M.V., Cantero-Martínez C., and Arrúe J.L., 2008. Tillage effects on soil organic carbon fractions in Mediterranean dryland agroecosystems. Soil Sci. Soc. Am. J., 72, 541-547.

Baldock J.A. and Skjemstad J.O., 2000. Role of the soil matrix and minerals in protecting natural organic materials against biological attack. Organic Geochemistry, 31, 697-710.

Bandick A.K. and Dick R.P., 1999. Field management effects on soil enzyme activities. Soil Biol. Biochem., 31, 1471-1479.

Cambardella C.A., Gajda A.M., Doran J.W., Wienhold B.J., and Kettler T.A., 2001. Estimation of particulate and total organic matter by weight loss-on-ignition. In: Assessment Methods for Soil Carbon (Eds R. Lal, J.M. Kimble, R.F. Follett, B.A. Stewart). CRC Press LLC, Boca Raton, FL, USA.

Cambardella C.A. and Elliott E.T., 1992. Particulate soil organic matter. Changes across a grassland cultivation sequence. Soil Sci. Soc. Am. J., 56, 777-783.

Czyż E.A. and Dexter A.R., 2008. Soil physical properties under winter wheat grown with different tillage systems at selected locations. Int. Agrophysics, 22, 191-200.

Czyż E.A. and Dexter A.R., 2009. Soil physical properties as affected by traditional, reduced and no-tillage for winter wheat. Int. Agrophys., 23, 319-326.
Czyż E.A. and Dexter A.R., 2011. Turbidity. In: Encyclopedia of Agrophysics (Eds J. Gliński, J. Horabik, J. Lipiec). Springer Press, Dordrecht-Heidelberg-London- New York.

Czyż E.A. and Dexter A.R., 2015. Mechanical dispersion of clay from soil into water: readily-dispersed and spontaneouslydispersed clay Int. Agrophys., 29, 31-37.

Czyż E.A. and Dexter A.R., and Terelak H., 2002. Content of readily dispersible clay in the arable layer of some Polish soils. In: Sustainable Land Management - Environmental Protection - A Soil Physical Approach (Eds M. Pagliai, R. Jones). Advances in Geoecology, Catena Verlag, Germany.

Dao T.H., 1996. Tillage system and crop residue effects on surface compaction of a Paleustill. Agron. J., 88, 141-148.

Dexter A.R. and Czyż E.A., 2000. Effects of soil management on the dispersibility of clay in a sandy soil. Int. Agrophysics, 14, 269-272.

Dexter A.R., Richard G., Arrouays D., Czyż E.A., Jolivet C., and Duval O., 2008. Complexed organic matter controls soil physical properties. Geoderma, 144, 620-627.

Dick R.P., Breakwell D.P., and Turco R.F., 1996. Soil enzyme activities and biodiversity measurements and integrative microbial indicators. In: Methods of assessing soil quality. Soil Science Society of America Publication, Madison, WI, USA.

Doran J.W. and Parkin T.B., 1994. Defining and assessing soil quality. In: Soil Science Society of America, American Society of Agronomy (Eds J.W. Doran, D.C. Coleman, D.E. Bezdicek, B.A. Stewart). Defining Soil Quality for a Sustainable Environment. Special Publication, Madison, WI, USA.

Doran J.W. and Parkin T.B., 1996. Quantitative indicators of soil quality: A minimum data set. In: Methods for Assessing Soil Quality (Eds J.W. Doran, A.J. Jones). SSSA Special Publication 49, Madison, WI, USA.

Etana A., Rydberg T., and Arvidsson J., 2009. Readily dispersible clay and particle transport in five Swedish soils under long-term shallow tillage and mouldboard ploughing. Soil Till. Res., 106, 79-84.

Franzluebbers A.J., 2002. Soil organic matter stratification ratio as an indicator of soil quality. Soil Tillage Res., 66, 95-106.

Gajda A.M., 2010. Microbial activity and particulate organic matter content in soils with different tillage system use. Int. Agrophys., 24, 129-138.

Gajda A.M., Doran J.W., Kettler T.A., Wienhold B.J., Pikul J.L.Jr., and Cambardella C.A., 2001. Soil quality evaluations of alternative conventional management systems in the great plains. In: Assessment Methods for Soil Carbon (Eds R. Lal, J.M. Kimble, R.F. Follett, B.A. Stewart). CRC Press LLC, Boca Raton, FL, USA.

Green V.S. and Stott D.E., and Diack M., 2006. Assay for fluorescein diacetate hydrolytic activity: optimization for soil samples. Soil Biol. Biochem., 38, 693-701.

Gregorich E.G., Carter M.R., Angers D.A., Monreal C.M., and Ellert B.H., 1994. Towards a minimum data set to assess soil organic matter quality in agricultural soils. Can. J. Soil Sci., 74, 367-385.

Gupta V.V.S.R., Roper M.M., Kirkegaard J.A., and Angus J.F., 1994. Changes in microbial biomass and organic matter levels during the first year of modified tillage and stubble management practices on a red earth. Australian J. Soil Res., 32, 1339-1354. 
Haynes R.J.,1999. Labile organic matter fractions and aggregate stability under short-term grass-based leys. Soil Biology Biochemistry, 31, 1821-1830.

Ishaq M., Ibrahim M., and Lal R., 2002. Tillage effects on soil properties at different levels of fertilizer application in Punjab, Pakistan. Soil Till. Res., 68, 93-99.

Karlen D.L., Kovar J.L., Cambardella C.A., and Colvin T.S., 2013. Thirty-year tillage effects on crop yield and soil fertility indicators. Soil Till. Res., 130, 24-41.

Król A., Lipiec J., Turski M., and Kuś J., 2013. Effects of organic and conventional management on physical properties of soil aggregates. Int. Agrophys., 27, 15-21.

Kuś J. and Jończyk K., 2008. Influence of organic and conventional crop production system on some parameters of soil fertility. J. Res. Appl. Agric. Eng., 53, 161-165.

López C.V.G, García M. del C.C., Fernández F.G.A., Bustos C.S., Chisti Y., and Sevilla J.M.F., 2010. Protein measurements of microalgal and cyanobacterial biomass. Bioresour. Technol., 101, 7587-7591.

Marinari S., Mancinelli R., Campiglia E., and Grego S., 2006. Chemical and biological indicators of soil quality in organic and conventional farming systems in Italy. Ecological Indicators, 6, 701-711.

Martín-Lammerding D., Hontoria C., Tenorio J.L., and Walter I., 2011. Mediterranean dryland farming: effect of tillage practices on selected soil properties. J. Agron., 103, 382-389.

Martín-Lammerding D., Tenorio L., Albarrán M.M., Zambrana E., and Walter I., 2013. Influence of tillage practices on soil biologically active organic matter content over a growing season under semiarid Mediterranean climate. Spanish J. Agric. Res., 11(1), 232-243.

Martyniuk S., Koziel M., Stalenga J., and Jończyk K., 2015. Labile fractions of soil organic matter and microbial characteristics of soil under organic and conventional crop management systems. Biol. Agric. Horticulture, 31(1), 1-6.

Rahman M.H., Okubo A., Sugiyama S., and Mayland H.F., 2008. Physical, chemical and microbiological properties of an Andisol as related to land use and tillage practice. Soil Till. Res., 101, 10-19.

Rasmussen K.J., 1999. Impact of ploughless soil tillage on yield and soil quality: a Scandinavian review. Soil Till. Res., 53, 3-14.

Reeves D.W., 1997. The role of soil organic matter in maintaining soil quality in continuous cropping system. Soil Till. Res., 43, 131-167.

Rosell R.A., Gasparoni S.C., and Galatini S.A., 2001. Soil organic matter evaluation. In: Management of Carbon Sequestration in Soils. Advances in Soil Science (Eds R., Lal, J.M. Kimble, R.F. Follette, B.A. Stewart). CRC Press, Boca Raton, FL, USA.
Sainju U.M., Lenssen A., Caesar-TonThat T., and Waddell J., 2006. Tillage and crop rotation effects on dryland soil and residue carbon and nitrogen. Soil. Sci. Soc. Am. J., 70, 668-678.

Salvo L., Hernandez J., and Ernst O., 2010. Distribution of soil organic carbon in different size fractions, under pasture and crop rotations with conventional tillage and no-till systems. Soil Till. Res., 109, 116-122.

Schulte E.E. and Hopkins B.G., 1996. Estimation of soil organic matter by weight loss-on-ignition. In: Soil Organic Matter: Analysis and Interpretation. SSSA Special Publication No. 46., Soil Science Society of America, Madison, WI, USA.

Sequeira C.H., Alley M.M., and Jones B.P., 2010. Evaluation of potentially labile soil organic carbon and nitrogen fractionation procedures. Soil Biol. Biochem., 43, 438-444.

Stott D.E. and Diack M., 2004. Changes in surface soil physical, chemical and biochemical properties under long-term management practices on a temperate mollisol. ISCO, 13th Int. Soil Conservation Organisation Conf. Brisbane, July 4-9. Conserving Soil and Water for Society: Sharing Solutions Paper No. 656, 1-4.

Stutter M.I., Lumsdon D.G., Billett M.F., Low D., and Deeks L.K., 2009. Spatial variability in properties affecting organic horizon carbon storage in upland soils. Soil Sci. Soc. Am. J., 73, 1724-1732.

Tebrüge F. and Düring R.A., 1999. Reducing tillage intensity a review of results from a long-term study in Germany. Soil Till. Res., 53, 15-28.

Wander M., 2004. Soil organic matter fractions and their relevance to soil function. In: Soil Organic Matter in Sustainable Agriculture (Eds F. Magdoff, R.R. Weil). CRC Press, Boca Raton, FL, USA.

Watts C.W. and Dexter A.R., 1997. The influence of organic matter in reducing the destabilization of soil by simulated tillage. Soil Till. Res., 42, 253-275.

Watts C.W., Dexter A.R., Dumitru E., and Arvidsson J., 1996a. An assessment of the vulnerability of soil structure to destabilization during tillage. Part I - A laboratory test. Soil Till. Res., 37, 161-174.

Watts C.W., Dexter A.R., Dumitru E., and Canarache A., 1996b. Structural stability of two Romanian soils as influenced by management practices. Land Degradation Development, 7, 217-238.

Watts C.W., Dexter A.R., and Longstaff D.J., 1996c. An assessment of the vulnerability of soil structure to destabilization during tillage. Part II - Field trials. Soil Till. Res., 37, 175-190

Yoo G. and Wander M.M., 2008. Tillage effects on aggregate turnover and sequestration of particulate and humified soil organic carbon. Soil Sci. Soc. Am. J., 72, 670-676. 